\title{
Membracidae diversity (Hemiptera: Auchenorrhyncha) in an Atlantic Forest area, Paraíba, Brazil, with preliminary comments on collection methods, spatial distribution and estimated species richness Diversidade de Membracidae (Hemiptera: Auchenorrhyncha) em uma área da Mata Atlântica, Paraíba, Brasil, com comentários preliminares sobre métodos de coleta, distribuição espacial e riqueza estimada
}

\author{
Antonio José Creão-Duarte', Alessandre Pereira-Colavite', Wellington Emanuel dos Santos', \\ Suênia Alcântara Barbosa"', Valberta Alves Cabral', Aline Lourenço', Izabela Souza Braga', Wylma Regina da Silva' \\ Universidade Federal da Paraíba. João Pessoa, Paraíba, Brasil \\ "Pesquisadora independente. Sobral, Ceará, Brasil
}

\begin{abstract}
In order to document the Membracidae of an area of the Brazilian Atlantic Forest in Paraíba, four collection methods were employed, distributed in 100 sample units during ten days in November 2014. A total of 1,182 membracids of 27 species were collected. The assemblages were marked with a high dominance, since six species accounted for $80.63 \%$ of the total number of individuals captured. Species with more than ten individuals were associated with the three environments of the forest: canopy, understory, and edge. The importance of the four sampling methods in the final membracid composition was evaluated through the Jaccard similarity index and its complement, where the values of complementarity were superior to the values of similarity, suggesting the dissimilarity of assemblages inventoried by each method. The observed richness corresponds to $90.0 \%$ and $79.4 \%$ of the richness estimated by Chao 1 and Chao 2 . The richness estimated by Chao1 is within the upper limit of the confidence interval ( $95 \%)$ in the last plot of the species accumulation curve, while the richness estimated by Chao 2 is above this limit. The additional sampling effort needed to collect 95\% of the estimated richness is 969 individuals for Chao1 and 317 sample units for Chao2.
\end{abstract}

Keywords: Abundancy. Species diversity estimators. Faunistic inventory. Treehoppers.

Resumo: Para documentar os membracídeos em uma área de Mata Atlântica na Paraíba, quatro métodos de coleta, distribuídos em 100 unidades amostrais, foram utilizados durante dez dias, em novembro de 2014. Foram coletados 1.182 espécimes de 27 espécies, sendo essa taxocenose marcada por alta dominância, pois representantes de apenas seis espécies foram responsáveis por 80,63\% do número total de indivíduos coletados. Espécies com mais de dez indivíduos foram associadas a três ambientes da floresta (dossel, sub-bosque e borda). A importância dos quatro métodos de amostragem na composição final da taxocenose foi avaliada através do índice de similaridade de Jacard e de seu complemento, onde os valores de complementaridade foram superiores aos de similaridade, sugerindo a dissimilaridade das taxocenoses inventariadas por cada método. A riqueza observada corresponde a 90\% e 79,4\% da riqueza estimada por Chao1 e Chao2. A riqueza estimada por Chao1 encontra-se dentro do limite superior do intervalo de confiança (95\%) no último lançamento da curva de acumulação de espécies, enquanto a riqueza estimada por Chao2 encontra-se acima deste limite. O esforço adicional de amostragem, necessário para coletar 95\% da riqueza estimada, é de 969 indivíduos para Chao1 e 317 unidades amostrais para Chao2.

Palavras-chave: Abundância. Estimadores de diversidade de espécies. Inventário faunístico. Membracídeos.

CREÃO-DUARTE, A. J., A. PEREIRA-COLAVITE, W. E. SANTOS, S. A. BARBOSA, V. A. CABRAL, A. LOURENÇO, I. S. BRAGA \& W. R. SILVA, 2017. Membracidae diversity (Hemiptera, Auchenorrhyncha) in an Atlantic Forest area, Paraíba, Brazil, with preliminary comments on collection methods, spatial distribution and estimated species richness. Boletim do Museu Paraense Emílio Goeldi. Ciências Naturais 12(1): 11-21.

Autor para correspondências: Antonio José Creão-Duarte. Universidade Federal da Parába. Centro de Ciências Exatas e da Natureza. Departamento de Sistemática e Ecologia. Castelo Branco, s/n. João Pessoa, PB, Brasil. CEP 58059-900 (creaoduarte@yahoo.com.br).

Recebido em 13/04/2017

Aprovado em 11/06/2017

Responsabilidade editorial: Fernando da Silva Carvalho Filho

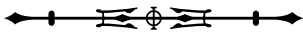




\section{INTRODUCTION}

The heightened degradation of tropical forests with irreversible reduction in the number of species has led us to reflect on the words of May (1988), that Biological Conservation is a science with limited time. The nonexistent consensus of an overall estimation of species richness (Mora et al., 2011) has hindered our understanding of the magnitude of environmental changes in the Anthropocene (Caley et al., 2014). Thus, local species listings are required, since richness at a global scale is inferred from local richness data (Magurran, 2011).

The use of arthropods, and insects in particular, has been supported in monitoring the sustainable use of tropical forests, since they respond quickly to environmental changes (Alarape et al., 2015). Membracids are one of the most appropriate groups in this regard, mainly due to the diversity of plants that host them (Brown, 1997).

The Membracidae (Hemiptera: Auchenorrhyncha) is structured into nine subfamilies, 49 tribes, 441 genera, and more than 3,200 species (Deitz \& Wallace, 2011). The species belonging to this family are distributed worldwide, with an increase in recorded diversity in the Neotropical Region (Wood, 1993). They are specific or generalist plant parasites (Creão-Duarte et al., 2012, 2016) that extract sap and consequently produce honeydew that attracts Hymenoptera, with which these Hemiptera establish biological associations (Olmstead \& Wood, 1990; Wood, 1993; Fagundes et al., 2012). They are recognized by their well-developed pronotum that covers the abdomen and almost all of the wings in some species, and may assume a similar appearance to plant structures such as buds, leaves and thorns (Wallace \& Deitz, 2007). The objectives of this study were to document the overall diversity of membracids in a remnant of the Atlantic Forest in Paraíba, Brazil, based on four collection methods. Additionally, we provide preliminary comments on the collection methods used, the spatial distribution of the species, and estimated richness of treehoppers.

\section{MATERIAL AND METHODS}

\section{STUDY AREA}

Fieldwork was conducted from 20 to 29 November 2014, in three large remnants of the Atlantic Forest, in campus I of the Federal University of Paraíba, in João Pessoa, Paraíba, Brazil, totaling 19.3 hectares. These three remnants are close together and were therefore considered as a single study area with the same meteorological conditions as the metropolitan region of João Pessoa: temperature of $25.2^{\circ} \mathrm{C}$, total annual precipitation of $1,888 \mathrm{~mm}$, and relative humidity of $77.7 \%$ (averages from the last ten years) (INMET, 2016).

\section{SAMPLING}

The collections were based on 100 sample units distributed into four capture methods: 40 yellow pan traps (understory); 20 yellow adhesive cards (canopy); ten nocturnal collections with light traps, and 30 active collections (manual process).

The soil pitfall trays were randomly arranged $5 \mathrm{~m}$ from the forest edge, at least $20 \mathrm{~m}$ apart, and were composed of a rectangular plastic yellow container $30 \times 22 \times 7 \mathrm{~cm}$, filled with water and detergent. The yellow adhesive cards Promip ${ }^{\circledR}$ $(23 \times 22 \mathrm{~cm})$ were randomly placed in the tree canopy $40 \mathrm{~m}$ from the edge, at least $30 \mathrm{~m}$ apart. The sampling duration for these methods was ten days.

The light traps used mixed mercury vapor lightbulbs of $250 \mathrm{~W}$ and $220 \mathrm{~V}$ on a white cloth background (1.7x $2 \mathrm{~m}$ ) and each sample unit corresponded to 90 minutes of collection, each unit was at least $80 \mathrm{~m}$ apart. Active collection was conducted along a demarcated transect at the edge of forest remnants, and each sample unit corresponded to a visual inspection along $30 \mathrm{~m}$ of the transect near plants at the edge, up to $2 \mathrm{~m}$ in height, interspersed by $10 \mathrm{~m}$, using killing jars and entomological nets for capture.

Species were identified by comparison using specimens from the reference collection, photos from a species database, and specialized bibliography. The specimens were incorporated into the Coleção Entomológica of the 
Departamento de Sistemática e Ecologia of the Federal University of Paraíba (DSEC). The photographs were made using a stereomicroscope (Leica $\left.{ }^{\circledR} / \mathrm{M} 205 \mathrm{C}\right)$ with a coupled high definition camera (Leica ${ }^{\circledR} / \mathrm{DFC} 295$ ) and a microcomputer, and the software Leica ${ }^{\circledR}$ Application Suite.

\section{DATA ANALYSIS}

The species list was organized by absolute and relative abundance. Species with more than ten individuals were associated with three forest environments: canopy, understory and edge. Edge species were those whose representatives were collected only in active collections conducted at the edge. Canopy species were those individuals collected on the cards, and understory species were those collected in trays. The light trap collects both canopy and understory specimens; thus, the environment was determined through occurrences in cards and trays.

In order to verify the importance of sampling methods in the final composition of the membracid assemblage, the four sampling methods were evaluated in pairs for similarity and complementarity using the Jaccard index in the program PAST 3.13 (Hammer et al., 2001). The values for both similarity and complementarity vary from 0 to 1 and indicate none and total similarity, or total or no complementarity, that is, the smaller the similarity the more complementary the assemblages inventoried by the methods (Magurran, 2011).

Two non-parametric species richness estimators were used: Chao 1 (abundance data) and Chao2 (incidence data) in the program EstimateS, version 9.1.0 (Colwell, 2013). The data were subjected to 1,000 randomizations without replacement (i.e. the samples were added to the analysis in random order and each was selected only once) (Walther \& Moore, 2005; Colwell, 2013). The observed species curve $\left(\mathrm{S}_{\text {obs }}\right)$, with a confidence interval of $95 \%$, is equivalent to the species accumulation curve and was constructed by EstimateS. In terms of number of individuals (Chao1) and samples (Chao2), the complement required to reach $95 \%$ of the estimated richness was calculated using the procedures of Chao et al. (2009).

\section{RESULTS AND DISCUSSION}

A total 1,182 individuals was collected of 27 membracid species (Figures 1A-1L and 2A-2O). However, four species could not be identified beyond genus (Table 1). Taxonomic issues involving uncertain identification were reported by Wallace (2008) and Wallace \& Maloney (2010) in studies of membracid occurrence on oak in the Delaware Water Gap National Recreation Area and Pocono Till Barrens, Long Pond, Pennsylvania, respectively. This difficulty is expressed in other listings of Membracidae species richness (Lopes, 1995; Johnson \& Freytag, 1997; Lencioni Neto, 2011; Creão-Duarte et al., 2012).

A total of 565 individuals of 19 species was collected in the forest interior, including 167 individuals of 11 species in 20 canopy cards, 360 of 13 species in 40 trays, and 38 individuals of eight species in ten collections with light traps. At the forest edge, 617 individuals of 21 species were collected during 30 active collections (Table 1). Several collection methods have been used in isolation or together in the capture of membracids, such as active collection (Lopes, 1995; CreãoDuarte et al., 2012, 2016), yellow adhesive cards (Kopp \& Yonke, 1970; Mason \& Loye, 1981; Johnson \& Freytag, 1997; Wallace \& Maloney, 2010), malaise and light trap (Godoy et al., 2006), and atomizers (Albertson \& Dietrich, 2006).

Six species contributed $80.63 \%$ of the total abundance: Enchenopa gladius (Fabricius, 1775), 27.07\% (Figure 1A); Erechtia gibbosa (DeGeer, 1773), 17.26\% (Figure 1B); Todea sp., 12.35\% (Figure 1C); Membracis luizae Evangelista \& Sakakibara, 2010, 8.97\% (Figure 1D); Bolbonota melaena (Germar, 1835), 7.53\% (Figure 1E); and Enchenopa squamigera (Linnaeus, 1767), 7.45\% (Figure 1F). The observed distribution pattern of species frequency (Figure 3) is represented by a few species with many individuals and many species with few individuals. This pattern repeats what Bartlett et al. (2008) found for membracids in Little Orleans, Maryland, where four species accounted for $85.2 \%$ of the total abundance. Studies involving other taxonomic groups report the same tendency of dominance by a few species of the assemblages, such as Tephritidae (Diniz et al., 2010) and Braconidae (Ruiz-Guerra et al., 2015). 
Sixteen species were associated with one of the three forest environments. Those considered edge species were the following: Membracis luizae, Bolbonota melaena, Enchenopa squamigera, Enchenopa concolor (Fairmaire,
1846) (Figure 1H), Enchophyllum ensatum (Coquebert, 1801) (Figure 1J), Cyphonia nordestina Sakakibara, 1968 (Figure 1I), and Leioscyta spiralis (Haviland, 1925) (Figure 1L). With the exception of $B$. melaena, none of these species

Table 1. Number of individuals of membracid species captured using 100 sample units distributed into four collection methods: A (yellow adhesive cards); B (yellow pan traps); C (light traps); D (active collection); and AC (accumulated), in remnants of Atlantic Forest in João Pessoa, Paraíba. Highlighted species were not associated with a specific environment.

\begin{tabular}{|c|c|c|c|c|c|c|c|}
\hline \multirow{2}{*}{ Species } & \multicolumn{4}{|c|}{ Collection method } & \multirow{2}{*}{ Total } & \multirow{2}{*}{$\%$} & \multirow{2}{*}{$\% A C$} \\
\hline & A & B & C & D & & & \\
\hline Enchenopa gladius (Fabricius, 1775) & 12 & 305 & 3 & 0 & 320 & 27.07 & 27.07 \\
\hline Erechtia gibbosa (DeGeer, 1773) & 29 & 4 & 0 & 171 & 204 & 17.26 & 44.33 \\
\hline Todea sp. & 68 & 1 & 5 & 72 & 146 & 12.35 & 56.68 \\
\hline Membracis luizae Evangelista \& Sakakibara, 2010 & 0 & 18 & 0 & 88 & 106 & 8.97 & 65.65 \\
\hline Bolbonota melaena (Germar, 1835) & 1 & 1 & 0 & 87 & 89 & 7.53 & 73.18 \\
\hline Enchenopa squamigera (Linnaeus, 1767) & 0 & 3 & 0 & 85 & 88 & 7.45 & 80.63 \\
\hline Harmonides dispar (Fabricius, 1803) & 12 & 0 & 17 & 7 & 36 & 3.05 & 83.67 \\
\hline Enchenopa concolor (Fairmaire, 1846) & 0 & 6 & 0 & 27 & 33 & 2.79 & 86.46 \\
\hline Cyphonia nordestina Sakakibara, 1968 & 0 & 0 & 0 & 22 & 22 & 1.86 & 88.32 \\
\hline Enchophyllum ensatum (Coquebert, 1801) & 0 & 0 & 0 & 22 & 22 & 1.86 & 90.19 \\
\hline Tropidoscyta torva (Germar, 1835) & 20 & 1 & 0 & 0 & 21 & 1.78 & 91.96 \\
\hline Leioscyta spiralis (Haviland, 1925) & 0 & 2 & 0 & 18 & 20 & 1.69 & 93.65 \\
\hline Notocera camelina (Sakakibara, 1977) & 0 & 16 & 0 & 1 & 17 & 1.44 & 95.09 \\
\hline Procyrta pectoralis (Fabricius, 1803) & 9 & 1 & 2 & 0 & 12 & 1.02 & 96.11 \\
\hline Havilandia pruinosa (Haviland, 1925) & 9 & 1 & 0 & 1 & 11 & 0.93 & 97.04 \\
\hline Neotynelia martinsi Creão-Duarte \& Sakakibara, 2000 & 5 & 0 & 4 & 1 & 10 & 0.85 & 97.88 \\
\hline Notogonioides sinopae (Sakakibara, 1996) & 0 & 0 & 3 & 4 & 7 & 0.59 & 98.48 \\
\hline Cyphonia trifida (Fabricius, 1775) & 0 & 0 & 0 & 4 & 4 & 0.34 & 98.82 \\
\hline Tolania sp. & 0 & 0 & 3 & 0 & 3 & 0.25 & 99.07 \\
\hline Ceresa ustulata Fairmaire, 1846 & 0 & 0 & 0 & 2 & 2 & 0.17 & 99.24 \\
\hline Cymbomorpha olivacea (Fabricius, 1803) & 1 & 0 & 0 & 1 & 2 & 0.17 & 99.41 \\
\hline Tolania furcata-group sp. & 1 & 1 & 0 & 0 & 2 & 0.17 & 99.58 \\
\hline Ceresa vitulus (Fabricius, 1775) & 0 & 0 & 1 & 0 & 1 & 0.08 & 99.66 \\
\hline Enchenopa auridorsa Sakakibra \& Marques, 2007 & 0 & 0 & 0 & 1 & 1 & 0.08 & 99.75 \\
\hline Enchenopa monoceros (Germar, 1833) & 0 & 0 & 0 & 1 & 1 & 0.08 & 99.83 \\
\hline Erosne sp. & 0 & 0 & 0 & 1 & 1 & 0.08 & 99.92 \\
\hline Anobilia splendida Tode, 1966 & 0 & 0 & 0 & 1 & 1 & 0.08 & 100.00 \\
\hline Total number of individuals & 167 & 360 & 38 & 617 & 1,182 & 100 & \\
\hline Total number of species & 11 & 13 & 8 & 20 & 26 & & \\
\hline
\end{tabular}


were registered in the canopy or light trap. Membracis luizae is found on many edge plants, exotic and native (Sakakibara \& Evangelista, 2010), and some individuals of this species were collected in trays inside the forest which can be explained by the location of the trays close to the edge, an explanation that also holds for E. squamigera, $E$. concolor, and L. spiralis. Enchenopa gladius and Notocera camelina (Sakakibara, 1977) (Figure 2A) were considered understory species because they were captured mainly in trays and are the only species whose individuals were sighted inside the forest.

Procyrta pectoralis (Fabricius, 1803) (Figure 2B), Tropidoscyta torva (Germar, 1835) (Figure 1K), Havilandia pruinosa (Haviland, 1925) (Figure 2C), and Neotynelia martinsi Creão-Duarte \& Sakakibara, 2000 (Figure 2D) were considered canopy species, since their representatives were mainly collected in the canopy and light traps. Furthermore, even though $H$. pruinosa was not registered on the edge, it is common on Byrsonima sericea DC. (Malpighiaceae) that can be found along the edge. Harmonides dispar (Fabricius, 1803) (Figure 1G) was registered in adhesive cards (canopy), light traps, and active collection, but was considered a canopy species since the species captured at the edge were on regrowth of Pouteria grandiflora (A. DC.) Baehni (Sapotaceae), that is a large tree found in the interior of the forest reaching the canopy.

Erechtia gibbosa and Todea sp. were mainly represented in canopy and edge collections, that is, in places with higher

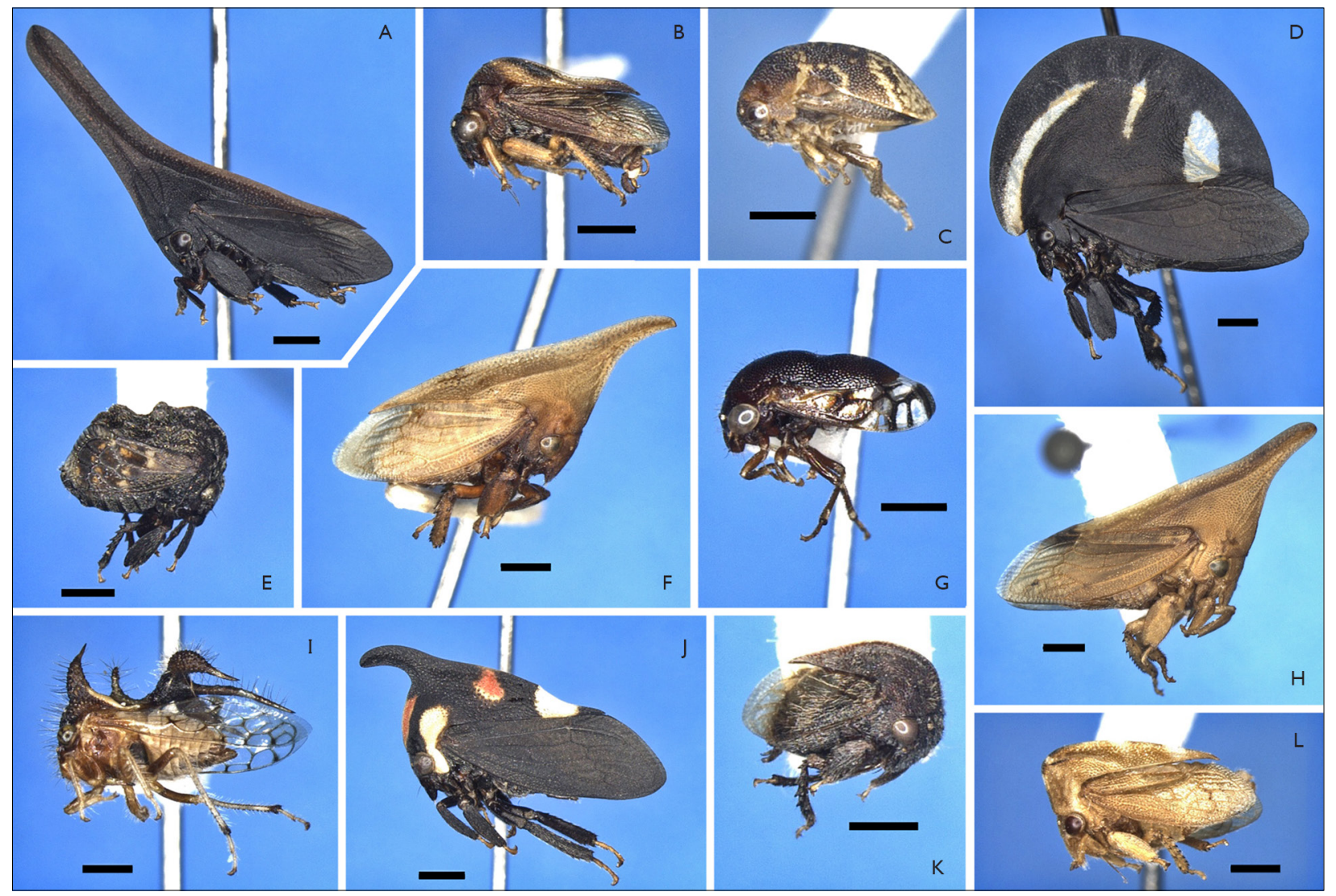

Figure 1. Collected Membracidae: A) Enchenopa gladius (Fabricius, 1775); B) Erechtia gibbosa (DeGeer, 1773); C) Todea sp.; D) Membracis luizae Evangelista \& Sakakibara, 2010; E) Bolbonota melaena (Germar, 1835); F) Enchenopa squamigera (Linnaeus, 1767); G) Harmonides dispar (Fabricius, 1803); H) Enchenopa concolor (Fairmaire, 1846); I) Cyphonia nordestina Sakakibara, 1968; J) Enchophyllum ensatum (Coquebert 1801); K) Tropidoscyta torva (Germar, 1835); L) Leioscyta spiralis (Haviland, 1925). Scale bar: $1 \mathrm{~mm}$.

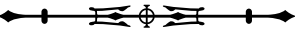


light incidence, possibly because they have host plants that are found in these two places, that may imply that they are generalist species. In a study of herbivorous insects in tropical forests, Basset (1999) concluded that generalists vary from $78-84 \%$ among sap-feeding insects (sap-sucking), and that compared to leaf-chewing insects (leaf-chewing) sap-sucking insects outnumber the latter more than twice.
In a study of membracid niche overlap in the Caatinga, Creão-Duarte et al. (2012) observed that most species were generalists. The same low species specificity of Hemiptera and Auchenorrhyncha herbivores was also found by Dem et al. (2013) in a tropical forest study in New Guinea.

In a meta-analysis with data from 31 studies conducted between 1994-2010, Guimarães et al. (2014)

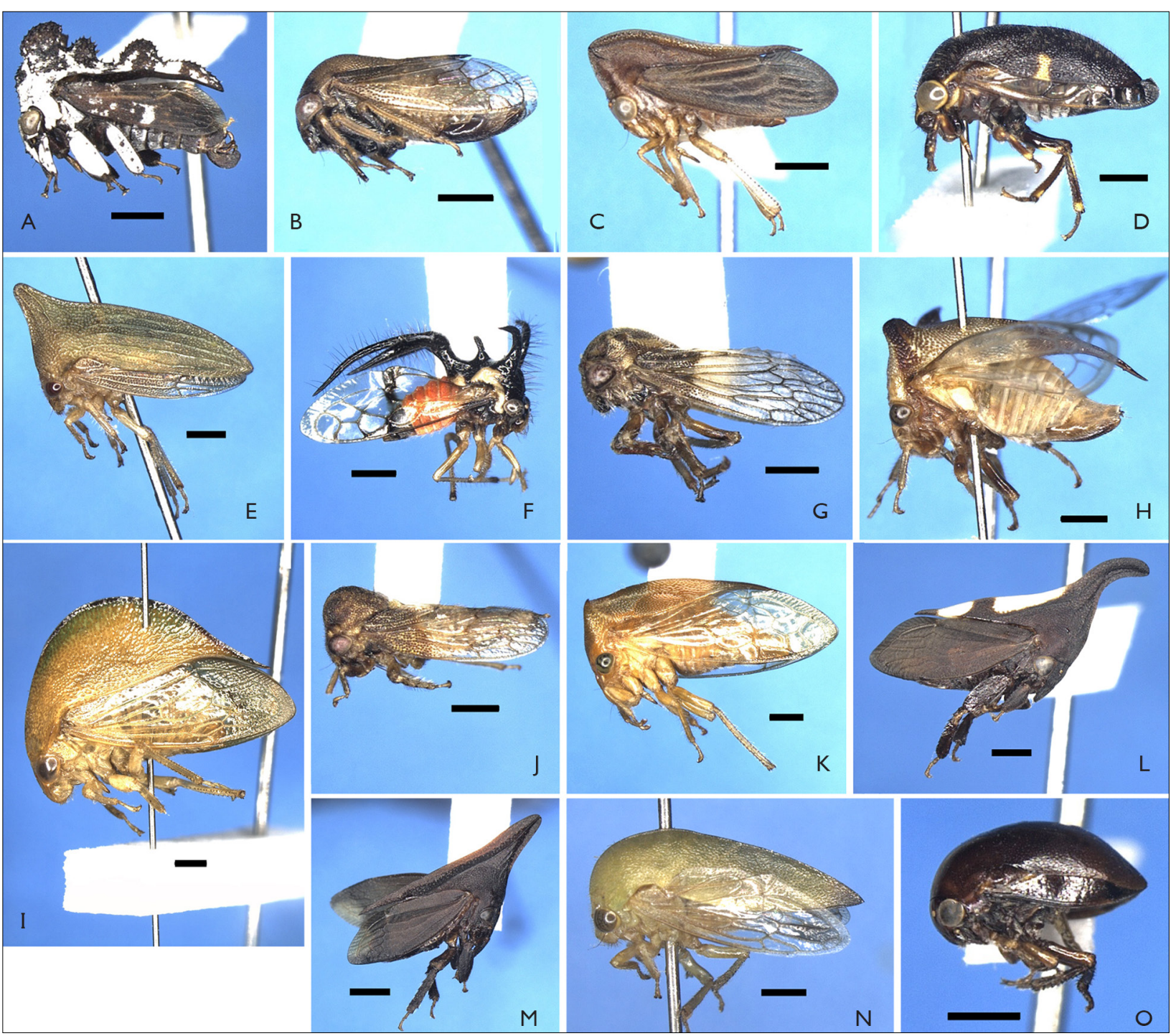

Figure 2. Collected Membracidae: A) Notocera camelina (Sakakibara, 1977); B) Procyrta pectoralis (Fabricius, 1803); C) Havilandia pruinosa (Haviland, 1925); D) Neotynelia martinsi Creão-Duarte \& Sakakibara, 2000; E) Notogonioides sinopae (Sakakibara, 1996); F) Cyphonia trifida (Fabricius, 1775); G) Tolania peltacauda-group sp.; H) Ceresa ustulata Fairmaire, 1846; I) Cymbomorpha olivacea (Fabricius, 1803); J) Tolania furcata-group sp.; K) Ceresa vitulus (Fabricius, 1775); L) Enchenopa auridorsa Sakakibra \& Marques, 2007; M) Enchenopa monoceros (Germar, 1833); N) Erosne sp.; O) Anobilia splendida Tode, 1966. Scale bar: $1 \mathrm{~mm}$.

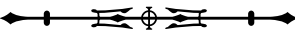




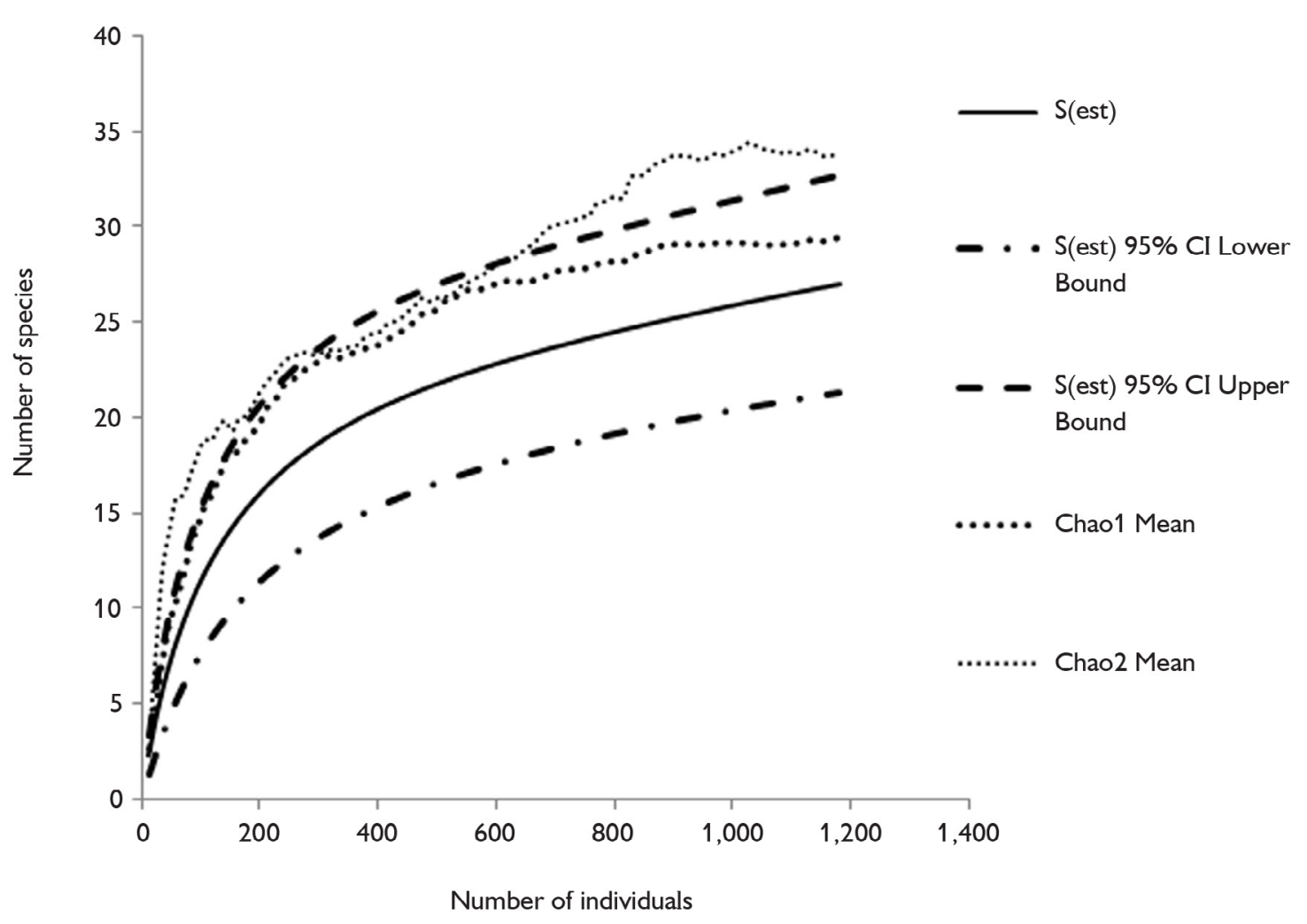

Figure 3. Frequency distribution of membracid species collected in Atlantic Forest remnants, Paraíba, using four collection methods.

reported that the edge exhibits a strong effect on plants and insects compared to the interior of the forest. In other words, edge plants have a higher rate of herbivory $(73.7 \%)$ and herbivorous insects (chewers) are more abundant (14\%) and have higher richness (65\%) when compared to other masticators in the forest interior. Iannuzzi et al. (2005) studied distribution patterns of families from five insect orders in three forest habitats (edge, trails, and interior) in a remnant of 390 hectares of Atlantic Forest in Pernambuco, Brazil, where the greatest abundance and species richness were observed at the edge compared to the interior for Hemiptera, including membracids.

The results (Table 2) show that the complementarity values exceed the similarity values of observed richness between five of the six possible pairs of collection methods, suggesting that the assemblages from each method are dissimilar to each other, reinforcing the necessity of the four different methods for inventorying membracids. Sørensen et al. (2002) used six sampling methods to estimate the diversity of spiders in the understory of a forest in Tanzania. The complementarity values obtained in the latter study indicated that of the possible 15 pairs formed by the six methods, only two had complementarity values below $50 \%$, and the two

Table 2. Similarity and complementarity indexes between pairs of membracid sampling methods in the Atlantic Forest (Paraíba). Complementary values are highlighted.

\begin{tabular}{c|c|c|c|c}
\hline & Card & Tray & Light & Active \\
\hline Card & & 0.5 & 0.36 & 0.28 \\
\hline Tray & 0.5 & & 0.17 & 0.36 \\
\hline Light & 0.64 & 0.83 & & 0.16 \\
\hline Active & 0.72 & 0.64 & 0.84 & \\
\hline
\end{tabular}

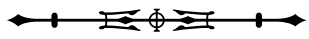


methods generated consistently different assemblages from those produced by the other four methods.

The values of species richness estimated by the Chao1 (30) and Chao2 (34) exceed the observed richness (27) (Table 3). The estimated richness with Chao1 is within the upper limit of the confidence interval (95\%) in the last plot of species accumulation curve, whereas the richness estimated by Chao2 is above this limit (Figure 4). Values of estimated richness by Chao2 surpassed the values estimated by Chao1, which is expected when uniques are

Table 3. Estimation of sampling effort for abundance (Chao1) and occurrence (Chao2) data in order to obtain 95\% of the estimated richness (g). Legends: $F_{1}=$ singletons; $F_{2}=$ doubletons; $Q_{1}=$ unique; $Q_{2}=$ duplicates; $N=$ individuals; $S_{\text {obs }}=$ observed species; $S_{\text {est }}=$ estimated species.

\begin{tabular}{|c|c|c|c|c|c|c|c|c|c|c|}
\hline \multirow{2}{*}{ Habitat, taxon and location } & \multirow{2}{*}{ N } & \multirow{2}{*}{$\mathrm{S}_{\text {obs }}$} & \multicolumn{4}{|c|}{ Chao1 } & \multicolumn{4}{|c|}{ Chao2 } \\
\hline & & & $\mathrm{S}_{\text {est }}$ & $F_{1}$ & $\mathrm{~F}_{2}$ & $g=95$ & $\mathrm{~S}_{\text {est }}$ & Q1 & $\mathrm{Q}_{2}$ & $g=95$ \\
\hline $\begin{array}{c}\text { Atlantic Forest, Membracidae, } \\
\text { João Pessoa, Paraíba }\end{array}$ & 1,182 & 27 & 30 & 5 & 3 & 969 & 34 & 7 & 2 & 317 \\
\hline
\end{tabular}

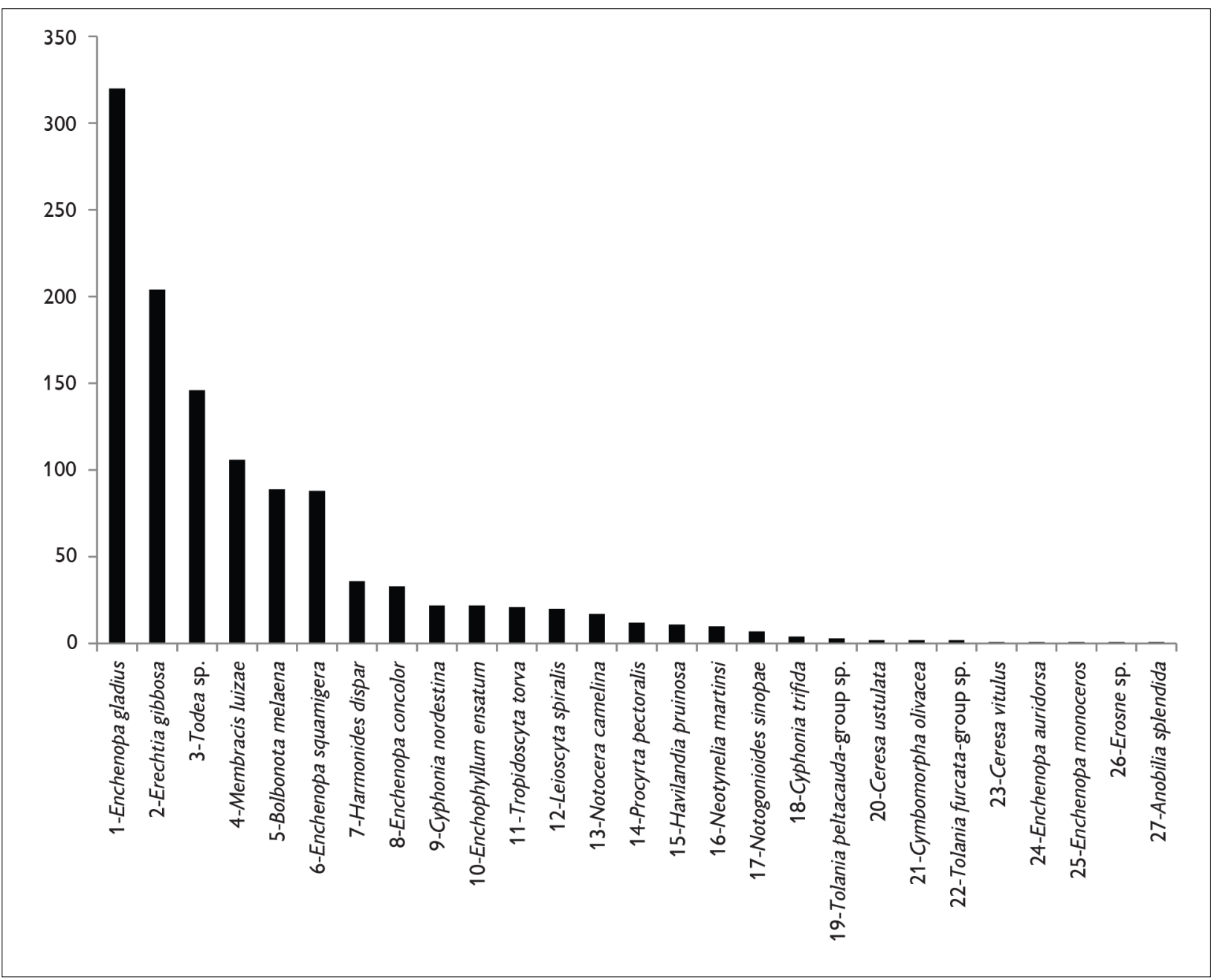

Figure 4. Species accumulation and estimated richness curve using Chao1 and Chao2.

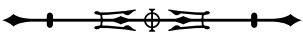


superior to singletons (Table 3). Other studies developed with other zoological groups presented similar comparative results between these estimators to those found in this study: Opiliones (Bragagnolo \& Pinto-da-Rocha, 2003), Arctiidae (Teston et al., 2012), and Scarabaeinae (Silva et al., 2012).

The observed richness corresponds to $90.0 \%$ and 79.4\% of the richness estimated by Chao1 and Chao2, respectively. Chao et al. (2009) proposed a method to estimate the increase in effort required to obtain $95 \%$ of the estimated richness when these estimators are employed. The results indicate the increase of individuals (Chao1) and samples (Chao2) to be used to reach $95 \%$ of the estimated richness (Table 3). The values of sampling effort for Chao2 require greater effort, since it implies more than tripling the original effort, that corresponds to 100 sample units. In a study of longitudinal variation in termites in 15 Atlantic Forest locations, Cancello et al. (2014) observed the need to increase the sampling effort in 11 sites, whose limits ranged from $50 \%$ to $1,400 \%$, in order to reach $95 \%$ of the estimated richness.

In summary, the use of the four collection methods during the ten days may be the basis of a collection protocol for membracids, bearing in mind the observed species richness (27) and abundance $(1,182)$. Considering the values estimated by Chao1 (28) and Chao2 (31), the 27 species represent a significant portion of the estimated richness for the 19 hectares of Atlantic Forest. However, to reach 95\% of the estimated richness by Chao2 would imply tripling the effort, that may not be feasible considering time and costs restraints. The methods used are appropriate and complementary. However, some adjustments are necessary, such as: 1) increase the number of canopy cards, since there is a high diversity in this location; 2) observe a greater distance between the trays with respect to the forest edge, in order to exclude the possibility of catching representatives of edge species with this method; and 3) since the edge of the remnant is not natural but anthropized, the active collection should be restricted to exotic plants and those naturally found at the edge.

\section{ACKNOWLEGEMENTS}

WES, VAC, AL and ISB would like to thank the Coordenação de Aperfeiçoamento de Pessoal de Nível Superior (CAPES) for the student scholarships. APC is grateful to the Conselho Nacional de Desenvolvimento Científico e Tecnológico (CNPq, process \#350052/2014-0) and Fundação de Apoio à Pesquisa do Estado da Paraíba (FAPESQ) for the research grant.

\section{REFERENCES}

ALARAPE, A. A., J. K. OMIFOLAJI \& G. S. MWANSAT, 2015. Butterfly species diversity and abundance in University of Ibadan Botanical Garden, Nigeria. Open Journal of Ecology 5: 352-360. DOI: http://dx.doi.org/10.4236/oje.2015.58029.

ALBERTSON, J. L. \& C. H. DIETRICH, 2006. Revision of the Neotropical treehopper genus Tolania (Hemiptera, Membracidae). Revista Brasileira de Zoologia 23(4): 915-993. DOI: http://dx.doi.org/10.1590/\$0101-81752006000400002.

BARTLETT, C. R., L. L. DEITZ, M. J. ROTHSCHILD \& M. S. WALLACE, 2008. Treehopper diversity (Hemiptera: Membracidae) of Little Orleans, Allegany Co., Maryland. Proceedings of the Entomological Society of Washington 110(1): 130-143. DOI: https://doi.org/10.4289/0013-8797-110.1.130.

BASSET, Y., 1999. Diversity and abundance of insect herbivores foraging on seedlings in a rainforest in Guyana. Ecological Entomology 24(3): 245-259.

BRAGAGNOLO, C. \& R. PINTO-DA-ROCHA, 2003. Diversidade de opiliões do Parque Nacional da Serra dos Órgãos, Rio de Janeiro, Brasil (Arachnida: Opiliones). Biota Neotropica 3(1): 1-20.

BROWN, K. S., 1997. Diversity, disturbance, and sustainable use of Neotropical forests: insects as indicators for conservation monitoring. Journal of Insect Conservation 1(1): 25-42. DOI: https://doi.org/10.1023/A:1018422807610.

CALEY, M. J., R. FISHER \& K. MENGERSE, 2014. Global species richness estimates have not converged. Trends in Ecology \& Evolution 29(4): 187-188. DOI: http://dx.doi.org/10.1016/j.tree.2014.02.002.

CANCELLO, E. M., R. R. SILVA, A. VASCONCELLOS, Y. T. REIS \& L. M. OLIVEIRA, 2014. Latitudinal variation in termite species richness and abundance along the Brazilian Atlantic Forest hotspot. Biotropica 46(4): 441-450. DOI: http://dx.doi.org/10.1111/btp.12120.

CHAO, A., R. K. COLWELL, C.-W. LIN \& N. J. GOTELLI, 2009. Sufficient sampling for asymptotic minimum species richness estimators. Ecology 90(4): 1125-1133. DOI: http://dx.doi.org/10.1890/07-2147.1. 
COLWELL, R. K., 2013. EstimateS: statistical estimation of species richness and shared species from samples. Version 9.1. User's guide and application. University of Connecticut, Storrs. Available at: <http://purl.oclc.org/estimates> Accessed on: June 15, 2015.

CREÃO-DUARTE, A. J., U. U. ANJOS \& W. E. SANTOS, 2012. Diversidade de membracídeos (Hemiptera, Membracidae) e sobreposição de recursos tróficos em área do semi-árido. Iheringia, série Zoologia 102(4): 453-458. DOI: http:// dx.doi.org/10.1590/S0073-47212012000400012.

CREÃO-DUARTE, A. J., M. I. M. HERNANDÉZ, R. R. A. D. RÓTHEA \& W. E. SANTOS, 2016. Temporal variation of Membracidae (Hemiptera: Auchenorrhyncha) composition in areas of Caatinga with different vegetation structures. Sociobiology 63(2): 826-830. DOI: http://dx.doi.org/10.13102/sociobiology.v63i2.1071.

DEITZ, L. L. \& M. S. WALLACE, 2011. Treehoppers: Aetalionidae, Melizoderidae, and Membracidae (Hemiptera). Available at: $<$ http://treehoppers.insectmuseum.org > . Accessed on: April 4, 2017.

DEM, F. F., A. J. A. STEWART, A. GIBSON, G. D. WEIBLEN \& V. NOVOTNY, 2013. Low host specificity in species-rich assemblages of xylem- and phloem-feeding herbivores (Auchenorrhyncha) in a New Guinea lowland rain forest. Journal of Tropical Ecology 29: 467-476. DOI: http://dx.doi.org/10.1017/S0266467413000540.

DINIZ, S., P. I. PRADO \& T. M. LEWINSOHN, 2010. Species richness in natural and disturbed habitats: Asteraceae and flower-head insects (Tephritidae: Diptera). Neotropical Entomology 39(2): 163171. DOI: http://dx.doi.org/10.1590/S1519-566X2010000200004.

FAGUNDES, R., K. DEL-CLARO \& S. P. RIBEIRO, 2012. Effects of the trophobiont herbivore Calloconophora pugionata (Hemiptera) on ant fauna associated with Myrcia obovata (Myrtaceae) in a montane tropical forest. Psyche 2012: 1-8. DOI: http:// dx.doi.org/10.1155/2012/783945.

GODOY, C., X. MIRANDA \& K. NISHIDA, 2006. Membrácidos de la América tropical. Treehoppers of tropical America: 1-356. Instituto Nacional de Biodiversidade (INBio), Santo Domingo de Heredia, Costa Rica.

GUIMARÃES, C. D. C, J. P. R. VIANA \& T. CORNELISSEN, 2014. A meta-analysis of the effects of fragmentation on herbivorous insects. Environmental Entomology 43(3): 537-545. DOI: https:// doi.org/10.1603/EN13190.

HAMMER, Ø., D. A. T. HARPER \& P. D. RYAN, 2001. PAST: Paleontological statistics software package for education and data analysis. Palaeontologia Electronica 4(1): 1-9.

IANNUZZI, L., V. S. BARBOSA, I. R. LEAL \&J. ALMEIDA-CORTEZ, 2005. Distribution pattern of herbivorous insects in a remnant of Brazilian Atlantic Forest. Neotropical Entomology 34(5): 701-711. DOI: http://dx.doi.org/10.1590/S1519-566X2005000500001.
INSTITUTO NACIONAL DE METEOROLOGIA (INMET), 2016. Available at: <http://www.inmet.gov.br>. Accessed on: October 26, 2016

JOHNSON, M. P. \& P. H. FREYTAG, 1997. Treehoppers (Homoptera: Membracidae) on pin oak in Kentucky. Journal of the Kansas Entomological Society 70(1): 21-30.

KOPP, D. D. \& T. R. YONKE, 1970. Annotated list of treehopper species (Homoptera: Membracidae) of Missouri and evaluation of collection methods. Transactions of the Missouri Academy of Science 4: 76-83.

LENCIONI NETO, F., 2011. Riqueza de espécies e distribuição espacial dos Membracidae (Hemiptera, Auchenorrhyncha) em uma pequena área do campus Urbanova da Universidade do Vale do Paraíba-SP, Brasil. Revista Univap 17(29): 80-98.

LOPES, B. C., 1995. Treehoppers (Homoptera. Membracidae) in southeastern Brazil: use of host plants. Revista Brasileira de Zoologia 12(3): 595-608. DOI: http://dx.doi.org/10.1590/S010181751995000300015.

MAGURRAN, A. E., 2011. Medindo a diversidade biológica: 1-261. Editora UFPR, Curitiba.

MASON, C. E. \& J. E. LOYE, 1981. Treehoppers (Homoptera: Membracidae) collected at multiple levels in a deciduous woodlot in Delaware. Entomological News 92(2): 64-68.

MAY, R. M., 1988. How many species are there on earth? Science 241(4872): 1441-1449. DOI: http://dx.doi.org/10.1126/ science.241.4872.1441.

MORA, C., D. P. TITTENSOR, S. ADL, A. G. B. SIMPSON \& B. WORM, 2011. How many species are there on Earth and in the ocean. PLoS Biology 9(8): e1001127. DOI: https:// doi.org/10.1371/journal.pbio.1001127.

OLMSTEAD, K. L. \& T. K. WOOD, 1990. The effect of clutch size and ant attendance on egg guarding by Entylia bactriana (Homoptera: Membracidae). Psyche 97(1-2): 111-120. DOI: http:// dx.doi.org/10.1155/1990/40278.

RUIZ-GUERRA, B., J. C. LÓPEZ-ACOSTA, A. ZALDIVARRIVERÓN \& N. VELÁZQUEZ-ROSAS, 2015. Braconidae (Hymenoptera: Ichneumonoidea) abundance and richness in four types of land use and preserved rain forest in southern Mexico. Revista Mexicana de Biodiversidad 86(1): 164-171. DOI: https://doi.org/10.7550/rmb.43865.

SAKAKIBARA, A. M. \& O. EVANGELISTA, 2010. Membracis foliata (Linnaeus) (Hemiptera: Membracidae) and allied species: an effort towards their determination. Journal of Natural History 44(35-36): 2131-2148. DOI: http:// dx.doi.org/10.1080/00222933.2010.485702. 
SILVA, P. G., L. D. AUDINO, J. M. NOGUEIRA, L. P. MORAES \& F.Z. VAZ-DE-MELLO, 2012. Escarabeíneos (Coleoptera: Scarabaeidae: Scarabaeinae) de uma área de campo nativo no bioma Pampa, Rio Grande do Sul, Brasil. Biota Neotropica 12(2): 246-252.

SØRENSEN, L. L., J. A. CODDINGTON \& N. SCHARFF, 2002. Inventorying and estimating subcanopy spider diversity using semi-quantitative sampling methods in an Afromontane forest. Environmental Entomological 31(2): 319-330. DOI: https://doi.org/10.1603/0046-225X-31.2.319.

TESTON, J. A., J. B. NOVAES \& J. O. B. ALMEIDA JÚNIOR, 2012. Abundância, composição e diversidade de Arctiinae (Lepidoptera, Arctiidae) em um fragmento de floresta na Amazônia Oriental em Altamira, PA, Brasil. Acta Amazonica 42(1): 105-114. DOI: http://dx.doi.org/10.1590/S0044-59672012000100013.

WALLACE, M. S., 2008. Occurrence of treehoppers (Hemiptera: Membracidae: Smilinae) on oaks in Delaware Water Gap National Recreation Area, 2004-2006. Journal of Insect Science 8(59): 1-16. DOI: http://dx.doi.org/10.1673/031.008.5901.
WALLACE, M. S. \& L. L. DEITZ, 2007. Treehoppers. In: W. O. LAMP, R. BERBERET, L. HIGLEY \& C. BAIRD (Ed.): Handbook of forage and rangeland insects: 106-108. Entomological Society of America, Annapolis.

WALLACE, M. S. \& S. M. MALONEY, 2010. Treehopper (Hemiptera: Membracidae) biodiversity and seasonal abundance in the Pocono till barrens, Long Pond, Pennsylvania. Proceedings of the Entomological Society of Washington 112(2): 281-294. DOI: https://doi.org/10.4289/0013-8797-112.2.281.

WALTHER, B. A. \& J. L. MOORE, 2005. The concepts of bias, precision and accuracy, and their use in testing the performance of species richness estimators, with a literature review of estimator performance. Ecography 28(6): 815-829. DOI: https://doi.org/10.1111/j.2005.0906-7590.04112.x.

WOOD, T. K., 1993. Diversity in the New World Membracidae. Annual Review of Entomology 38: 409-435. DOI: https://doi.org/10.1146/annurev.en.38.010193.002205. 
